\section{The Spectral Reflectance Response of 'Riviera' Common Bermudagrass to Increasing Saline Irrigation Concentrations}

\author{
Lakshmy Gopinath $^{1}$, Matthew Barton ${ }^{1}$, \\ and Justin Quetone Moss ${ }^{1}$
}

AdDitional INDEx wORDs. Cynodon dactylon, leaf firing, normalized difference vegetation index, salinity stress

SUMMARY. The availability of freshwater is a growing concern throughout the world as it is an increasingly valuable and limited resource. Alternative water resources such as recycled water low in quality and high in salinity are now frequently used to irrigate turfgrass. However, irrigating with highly saline water can affect the growth, performance, appearance, and quality of turfgrass. Bermudagrass (Cynodon sp.) is the most commonly used turfgrass throughout the southern United States. In this study, the spectral reflectance and visual response of 'Riviera' common bermudagrass (Cynodon dactylon) were evaluated by consecutively irrigating with 12 salinity concentrations $\left(4-48 \mathrm{dS} \cdot \mathrm{m}^{-1}\right)$ in increments of $4 \mathrm{dS} \cdot \mathrm{m}^{-1}$ via manual overhead irrigation for 30 days. The experiment was replicated in time in a controlled environment with four replications for each salinity treatment and control. 'Riviera' maintained a leaf firing (LF) value above 5 (rated on a scale from 1 to 9) when irrigated with $28 \mathrm{dS} \cdot \mathrm{m}^{-1}$ for 30 days. Also, the LF value did not fall below 2 when irrigated with a salinity concentration of $48 \mathrm{dS} \cdot \mathrm{m}^{-1}$ for 30 days, suggesting high salinity tolerance of 'Riviera'. However, in this study, the normalized difference vegetation index (NDVI) had a lower ability to detect the increase in salinity stress due to the limited area measured by the NDVI measuring device used. An increase in sodium ion concentration was observed in the shoot with increasing salinity concentrations. The NDVI was highly correlated $(r=0.93)$ to LF, indicating the usefulness of NDVI as a tool to measure the magnitude of salinity stress. The multiple linear regression analysis revealed that the data showed a linear response to salinity stress with $\mathrm{LF}\left(r^{2}=0.86\right)$ and NDVI $\left(r^{2}=0.76\right)$ decreasing linearly as the salinity concentration and days of treatment increased. This study provides an accurate depiction of the spectral and visual responses of 'Riviera' when exposed to multiple salinity concentrations with narrow increments.
$\mathrm{T}$ The degradation of existing freshwater resources and variations in rainfall patterns are straining water resources needed for a growing population. Recycled irrigation water, although often high in salinity, is becoming a more prevalent solution for irrigating landscapes (Devitt et al., 2004). However, irrigating with saline water could suppress plant growth and production

Received for publication 27 July 2020. Accepted for publication 6 Nov. 2020.

Published online 7 December 2020.

${ }^{1}$ Department of Horticulture and Landscape Architecture, Oklahoma State University, Stillwater, OK 74078

This work was supported in part by the U.S. Department of Agriculture National Institute of Food and Agriculture, Hatch Project, OKL02923.

J.Q.M. is the corresponding author. E-mail: justin. moss@okstate.edu.

This is an open access article distributed under the CC BY-NC-ND license (https://creativecommons.org/ licenses/by-nc-nd/4.0/).

https://doi.org/10.21273/HORTTECH04701-20
(Parida and Das, 2005). According to the two-phase plant growth response to salinity stress explained by Munns (1993), the first phase of growth reduction occurs due to the increase in salinity level in the soil, causing the water to move from the roots to the soil due to the difference in osmotic pressure. In the second phase, sodium $\left(\mathrm{Na}^{+}\right)$or chloride $\left(\mathrm{Cl}^{-}\right)$ ions may enter the transpiration stream, causing an increase in salt concentration in the cell wall or cytoplasm leading to cell injury (Munns, 1993).

Golf courses are one of the sites that use reclaimed or recycled water for irrigation (Harivandi, 2004). Approximately $12 \%$ of golf courses in the United States use recycled water for irrigation, and one of the reasons for not using recycled water is the possibility of low-quality turfgrass due to increased concentrations of salts (Throssell et al., 2009a). In contrast to many other areas of agriculture, turfgrass managers are primarily concerned with turfgrass quality and aesthetics rather than overall yield (Breuninger et al., 2013).

Salt glands that help in the excretion of excess $\mathrm{Na}^{+}$and $\mathrm{Cl}^{-}$ions have been reported in turfgrasses (Liphschitz and Waisel, 1974; Marcum and Murdoch, 1990). These glands helped in the excretion of salts, and the rate of excretion indicated the level of salinity tolerance of grasses in the subfamily Chloridoidea (Marcum, 1999). Bermudagrass (Cynodon sp.), belonging to the Chloridoidea, is one of the most important and widely adapted warm-season turfgrasses. Bermudagrasses have shown moderate salinity tolerance when subjected to varying concentrations of salinity (Marcum and Murdoch, 1994). Past research conducted on bermudagrass and other turfgrass species reported decreasing visual parameters of percent green cover, turf quality (TQ), and leaf firing (LF) (Xiang et al., 2017,2018 ), in addition to plant growth measurement, as plant salinity stress increases (Alshammary et al., 2008; Marcum, 1999; Uddin et al., $2011,2012)$. Because the increase in LF is based on the change in color of the leaves, LF can indicate injury in the plant due to salinity stress. 
Human evaluation of LF and TQ requires adequate training, consistency, and time (Bell et al., 2002a; Trenholm et al., 1999). Some of the alternative techniques to visual ratings are digital image analysis and the NDVI, which can provide a quantitative assessment of the magnitude of stress (Bell et al., 2002a; Sonmez et al., 2008). A strong correlation between NDVI and human evaluation of TQ and LF was reported for both clonal and common bermudagrass (Cynodon dactylon) in response to salinity stress (Xiang et al., 2017, 2018). Therefore, implementing digital image analysis or spectral reflectance techniques may be more efficient and consistent to reduce human variability when screening turfgrass species and cultivars for salinity tolerance.

Few studies have evaluated the salinity stress of bermudagrass using NDVI as the primary indicator of salinity stress applied via overhead watering. Overhead watering is most similar to industry practices and would expose all plant parts, including leaves, to salinity stress (Koch and Bonos, 2010). Also, no previous research has been conducted to understand the response of common bermudagrass cultivars to a larger number of treatments with smaller increments. Most studies in the past have used limited salinity treatments with larger increments, which resulted in a linear response (Marcum and Murdoch, 1990; Uddin et al., 2012; Xiang et al., 2017). However, small increments in salinity concentration may result in a nonlinear response. Therefore, the objective of this research is l) to evaluate the response of 'Riviera' common bermudagrass when irrigated with 12 salinity treatments $\left(4-48 \mathrm{dS} \cdot \mathrm{m}^{-1}\right)$ in increments of $4 \mathrm{dS} \cdot \mathrm{m}^{-1}$ and control via manual overhead irrigation for 30 $\mathrm{d}, 2$ ) to evaluate NDVI as a tool for validating visual ratings of salinity stress, and 3) to determine whether the smaller increments of salinity treatments resulted in a nonlinear response.

\section{Materials and methods}

The experiment was replicated in time at the Oklahoma State University (OSU) Controlled Environment Research Laboratory facility located in Stillwater, OK, from Jan. to June
2017 (study 1) and June to Nov. 2017 (study 2). Air temperatures within the greenhouse were maintained between 32 to $40{ }^{\circ} \mathrm{C}$ during the day and between 26 to $30{ }^{\circ} \mathrm{C}$ at night. Photosynthetically active radiation $(P A R)$ was maximized within the greenhouse by maintaining a photoperiod of $14 \mathrm{~h}$ using supplemental high-pressure sodium light. The average maximum daily $P A R$ during studies 1 and 2 was 608 and 526 $\mu \mathrm{mol} \cdot \mathrm{m}^{-2} \cdot \mathrm{s}^{-1}$, respectively. The common bermudagrass cultivar used for this study was Riviera. The cultivar was seeded at $0.246 \mathrm{~g}$ per cell into germination trays (American Plant Products, Oklahoma City, OK) containing sand in Jan. and June 2017 for studies 1 and 2 , respectively, and the seedlings were then transplanted to a 45-cm-long and 4-inch-diameter lysimeter tubes. The lysimeter tubes were filled with sand mixed with gypsum at $0.4 \mathrm{oz} / \mathrm{gal}$ to avoid calcium deficiency (Guimaraes et al., 2012). The sand was chosen as the growing medium to reduce the effects of nutrient uptake of grasses under sodium chloride stress.

During the establishment phase $(102 \mathrm{~d})$, the grasses were fertilized three times per week at $227 \mathrm{mg} \cdot \mathrm{L}^{-1}$ using a solution of $20 \mathrm{~N}-8.6 \mathrm{P}-16.6 \mathrm{~K}$ general-purpose fertilizer (J.R Peters, Allentown, PA). As a precautionary measure, the grasses were treated every 2 weeks with bifenthrin insecticide (Talstar; FMC Corp., Philadelphia, PA) rotated with abamectin (Avid 0.15EC; Syngenta, Greensboro, NC) and surfactant (Aduro; Winfield Solutions, St. Paul, MN) at labeled rates. During the establishment phase, the grasses were maintained at the height of 1 inch every 2 $\mathrm{d}$ for the first $30 \mathrm{~d}$. After transplanting to the lysimeter tubes, the grasses were maintained at 2 inches every 3 $\mathrm{d}$ throughout the remainder of the establishment phase.

SALINITY TREATMENTS. The study consisted of a control and 12 salinity treatments in increments of 4 $\mathrm{dS} \cdot \mathrm{m}^{-1}$ ranging from 4 to $48 \mathrm{dS} \cdot \mathrm{m}^{-1}$. There were four replications for each salinity treatment and control. Synthetic sea salt mix (Instant Ocean Sea Salt; Spectrum Brands, Blacksburg, VA) and tap water were used to prepare the saline solutions (Table 1). A nutrient solution containing 10 $\mathrm{mg} \cdot \mathrm{L}^{-1} 13 \mathrm{~N}-0.9 \mathrm{P}-10.8 \mathrm{~K}-6 \mathrm{Ca}-3 \mathrm{Mg}$ water-soluble fertilizer (Peters Excel 13-2-13 Plug \& Bedding Plant Special; ICL Specialty Fertilizers, Dublin, $\mathrm{OH}$ ) and magnesium sulfate at 7.5 $\mathrm{mg} \cdot \mathrm{L}^{-1}$ were added to both the control and salinity treatment as a nutrient source to reach the baseline salinity level of $1.5 \mathrm{dS} \cdot \mathrm{m}^{-1}$ (Xiang et al., 2017). The amount of sea salt mix added to each salinity treatment is shown in Table 2 , and an electrical conductivity meter was used to confirm the salinity concentration. The salinity treatments were initiated 102 $\mathrm{d}$ after transplanting. Treatments above $12 \mathrm{dS} \cdot \mathrm{m}^{-1}$ were initiated before day 1 to prevent salinity shock by gradually applying $8 \mathrm{dS} \cdot \mathrm{m}^{-1}$ per day such that the final salinity level was reached on day 1 (Uddin et al., 2012). Once the target salinity level was achieved, the salinity treatments were applied every day for $30 \mathrm{~d}$. The grasses were irrigated daily with $\mathrm{L} L$ of saline water using graduated jars. A flexible polyvinyl chloride coupler was attached to the lysimeter tubes during irrigation to prevent spillage and soak in the water.

The NDVI was determined using a turf color meter (Field Scout TCM 500 NDVI; Spectrum Technologies, Aurora, IL). This instrument measures the reflected light about from a 3-inch-diameter section of turfgrass using an internal light source to negate the effect of sunny vs. cloudy conditions, and the instrument also measures reflectance in the red $(660 \mathrm{~nm})$ and near-IR $(850 \mathrm{~nm})$ spectral bands. The grasses were visually evaluated for LF using a scale from 1 to 9 where $l=$ complete $L F$ and $9=$ no firing (Morris and Shearman, 2008). The NDVI and LF were determined every $3 \mathrm{~d}$. At the end of the $30 \mathrm{~d}$ of study 2 , shoots from all the four replications of each treatment were sent to the OSU Soil, Water and Forage Analytical Laboratory (SWFAL), Stillwater, OK, for plant tissue analysis.

EXPERIMENTAL DESIGN AND STATISTICAL ANALYSIS. The analytical design for this study was a randomized complete block design with four replications. All the parameters were analyzed using generalized linear mixed models (GLIMMIX) methods for repeated measures (SAS version 9.4; SAS Institute, Cary, NC). Replications and the trials (studies 1 and 2 ) were considered to be random effects, 
Table 1. Mean concentration of the constituents of synthetic sea salt (Instant Ocean Sea Salt; Spectrum Brands, Blacksburg, VA) used to prepare the 12 salinity treatments for irrigating 'Riviera' common bermudagrass.

\begin{tabular}{lc}
\hline Ion & Mean concn $\left.(\mathbf{g} \cdot \mathbf{k g})^{-1}\right)^{\mathbf{z}}$ \\
\hline Sodium $\left(\mathrm{Na}^{+}\right)$ & 10.78 \\
Potassium $\left(\mathrm{K}^{+}\right)$ & 0.42 \\
Magnesium $\left(\mathrm{Mg}^{++}\right)$ & 1.32 \\
Calcium $\left(\mathrm{Ca}^{++}\right)$ & 0.4 \\
Strontium $\left(\mathrm{Sr}^{++}\right)$ & 0.0088 \\
Chloride $\left(\mathrm{Cl}^{-}\right)$ & 19.29 \\
Sulfate $\left(\mathrm{SO}_{4}^{-}\right)$ & 2.66 \\
Bicarbonate $\left(\mathrm{HCO}_{3}^{-}\right)$ & 0.2 \\
Bromide $\left(\mathrm{Br}^{-}\right)$ & 0.056 \\
Fluoride $\left(\mathrm{F}^{-}\right)$ & 0.001 \\
\hline
\end{tabular}

${ }^{\mathrm{z}} 1 \mathrm{~g} \cdot \mathrm{kg}^{-1}=1000 \mathrm{ppm}$.

Table 2. Amount of synthetic sea salt (Instant Ocean Sea Salt; Spectrum Brands, Blacksburg, VA) added to each salinity treatment for irrigating 'Riviera' common bermudagrass.

\begin{tabular}{lc}
\hline Salinity treatment $\left(\mathbf{d S} \cdot \mathbf{m}^{-1}\right)^{\mathbf{z}}$ & Amount $\left(\mathbf{g} \cdot \mathbf{L}^{-1}\right)^{\mathbf{z}}$ \\
\hline Control & 0 \\
4 & 2.56 \\
8 & 5.12 \\
12 & 7.68 \\
16 & 10.24 \\
20 & 12.8 \\
24 & 15.36 \\
28 & 17.92 \\
32 & 20.48 \\
36 & 23.04 \\
40 & 25.6 \\
44 & 28.16 \\
48 & 30.72 \\
\hline
\end{tabular}

${ }^{\mathrm{z}} \mathrm{ldS} \cdot \mathrm{m}^{-1}=1 \mathrm{mmho} / \mathrm{cm}, \mathrm{lg} \cdot \mathrm{L}^{-1}=1000 \mathrm{ppm}$.

whereas the salinity treatment was considered to be fixed effects, and the days after treatment was a repeated measure. When the salinity treatment and days after treatment effect were found significant at $P<0.05$, salinity treatment means for LF and NDVI were separated within each rating date using Tukey's honestly significant difference (HSD) procedure test using SAS, at the 0.05 significance level. The correlation between LF and NDVI was performed using SAS procedure PROC CORR. Regression analysis was used to determine the relationships between salinity treatments and days after treatment (DAT) on NDVI and LF using the SAS procedure PROC REG. The $\mathrm{Na}^{+}$ and potassium $\left(\mathrm{K}^{+}\right)$ions concentration obtained from plant tissue analysis were subjected to analysis of variance (ANOVA) using SAS procedure PROC ANOVA. When the treatment effect was significant, the means were separated by using Tukey's HSD procedure at the 0.05 significance level.

\section{Results and discussion}

Significant differences among salinity treatments were observed for LF during the $30 \mathrm{~d}$ (Table 3 ). The control treatment did not show any firing and maintained a mean $\mathrm{LF}$ value of 9 throughout the study period. The mean LF for the 12 salinity treatments and the control on 0 DAT ranged from 9 to 7.5 , with treatments 0 to $24 \mathrm{dS} \cdot \mathrm{m}^{-1}$ having an LF of 9 . The decrease in LF value at 0 DAT for treatments 28 to $48 \mathrm{dS} \cdot \mathrm{m}^{-1}$ was due to the additional saline irrigation these treatments received before 0 DAT to avoid salinity shock. The mean LF of $4 \mathrm{dS} \cdot \mathrm{m}^{-1}$ was significantly different from the control at 21 DAT. This trend indicates that irrigation with low salinity concentrations over a long period could moderately affect the appearance of the turfgrass. However, 'Riviera' maintained an LF value $>5$ when irrigated with $28 \mathrm{dS} \cdot \mathrm{m}^{-1}$ for $30 \mathrm{~d}$. The LF values obtained for 44 and $48 \mathrm{dS} \cdot \mathrm{m}^{-1}$ are similar to the LF values obtained by Xiang et al. (2018) for 'Riviera' common bermudagrass at the end of $30 \mathrm{~d}$ at $45 \mathrm{dS} \cdot \mathrm{m}^{-1}(2.8)$. Also, 'Riviera' had a green leaf canopy area of $20 \%$ at $60 \mathrm{dS} \cdot \mathrm{m}^{-1}$ (Marcum and Pessarakli, 2006). In our study, 'Riviera' common bermudagrass maintained a mean LF rating above 2 when irrigated with $48 \mathrm{dS} \cdot \mathrm{m}^{-1}$ for $30 \mathrm{~d}$, which could be due to a relatively higher $\mathrm{Na}^{+}$excretion rate of the leaf salt glands (Marcum and Pessarakli, 2006). The plant tissue analysis obtained from SWFAL indicated an increase in $\mathrm{Na}^{+}$ions with an increase in salinity concentration in the shoot, confirming that the stress could be due to the $\mathrm{Na}^{+}$accumulation (Fig. 1). The increase in $\mathrm{Na}^{+}$ions in plant tissue was similar to the observations by Alshammary et al. (2008), Dudeck et al. (1983), and Marcum and Murdoch (1990, 1994), suggesting that increasing salinity concentrations may have reduced the excretion rate of salt glands and compartmentalization of $\mathrm{Na}^{+}$to vacuoles causing the buildup in the cytoplasm (Munns, 1993). Treatment had no effect on the percentage of $\mathrm{K}^{+}$ion concentration (Fig. 1). The stable concentrations of $\mathrm{K}^{+}$ions in the shoots in this study were in accordance with the trends reported by Marcum and Murdoch (1990) in which bermudagrasses maintained relatively stable $\mathrm{K}^{+}$concentrations with increasing salinity when compared with higher $\mathrm{K}^{+}$ion in seashore paspalum (Paspalum vaginatum) and st. augustinegrass (Stenotaphrum secundatum). High $\mathrm{Na}^{+}$can affect the uptake of other cations, especially $\mathrm{K}^{+}$, causing nutrient imbalance (Parida and Das 2005). The stable $\mathrm{K}^{+}$concentration in 'Riviera' might be one of the reasons for its better growth under salinity stress. However, this study was conducted for $30 \mathrm{~d}$; therefore, the effects of salinity at the concentrations evaluated do not necessarily imply long-term tolerance.

The test of fixed effects for NDVI readings revealed a significant interaction of salinity level and rating day. The NDVI values ranged from 0.773 (control) to $0.463\left(48 \mathrm{dS} \cdot \mathrm{m}^{-1}\right)$ at 30 DAT (Table 4). The control 
Table 3. Leaf firing values of 'Riviera' common bermudagrass for 12 salinity treatments and control on 11 rating dates.

\begin{tabular}{|c|c|c|c|c|c|c|c|c|c|c|c|}
\hline \multirow[b]{3}{*}{ Salinity treatment $\left(\mathrm{d} S \cdot \mathrm{m}^{-1}\right)^{\mathrm{z}}$} & \multicolumn{11}{|c|}{ Leaf firing $(1-9 \text { scale })^{y}$} \\
\hline & \multicolumn{11}{|c|}{ Days after treatment } \\
\hline & $\mathbf{0}$ & 3 & 6 & 9 & 12 & 15 & 18 & 21 & 24 & 27 & 30 \\
\hline 4 & 9.0 & 9.0 & 9.0 & 9.0 & 8.9 & 8.6 & 8.6 & $8.0^{*}$ & $8.0^{*}$ & $7.9^{*}$ & $8.0^{*}$ \\
\hline 8 & 9.0 & 9.0 & 8.9 & 8.6 & 8.3 & 8.3 & $8.0^{*}$ & $7.8^{*}$ & $7.5 * *$ & $7.5 * *$ & $7.4^{* *}$ \\
\hline 12 & 9.0 & 8.8 & $7.9^{*}$ & $7.8^{*}$ & $7.9^{*}$ & $7.6^{*}$ & $7.8^{*}$ & $7.0 * *$ & $6.9 * *$ & $7.0 * *$ & $6.9 * *$ \\
\hline 24 & 9.0 & $8.0^{*}$ & $7.3^{* *}$ & $7.0 * *$ & $6.9 * *$ & $6.5^{* *}$ & $6.5^{* *}$ & $6.0 * *$ & $5.8 * *$ & $5.9 * *$ & $5.6^{* *}$ \\
\hline 28 & 8.4 & $7.6^{*}$ & $6.9 * *$ & $6.9 * *$ & $6.6 * *$ & $6.3^{* *}$ & $7.1 * *$ & $6.3 * *$ & 5.5 ** & $5.6 * *$ & $5.5^{* *}$ \\
\hline 32 & $8.1^{*}$ & $7.5^{* *}$ & $6.8^{* *}$ & $6.6 * *$ & $6.6 * *$ & $5.9 * *$ & $6.1 * *$ & $5.9 * *$ & $5.3 * * *$ & $5.3 * * *$ & $4.9 * * *$ \\
\hline 36 & $8.0^{*}$ & $7.3 * *$ & $6.8 * *$ & $6.3^{* *}$ & $6.0 * *$ & $5.6 * *$ & $5.8 * *$ & 5.5 ** & $4.9 * * *$ & $4.8 * * *$ & $4.5^{* * *}$ \\
\hline 40 & $7.8^{*}$ & $7.3 * *$ & $5.8 * *$ & $5.5 * *$ & $5.1 * * *$ & $4.9 * * *$ & $5.0 * * *$ & $4.0 * * *$ & $4.0 * * *$ & $3.5^{* * *}$ & $2.8 * * *$ \\
\hline
\end{tabular}

${ }^{z_{c}}$ Riviera' common bermudagrass was evaluated by consecutively irrigating with 12 salinity concentrations $\left(4-48 \mathrm{dS} \cdot \mathrm{m}^{-1}\right)$ in increments of $4 \mathrm{dS} \cdot \mathrm{m}^{-1}$ and a control via manual overhead irrigation for $30 \mathrm{~d} ; \mathrm{l} \mathrm{dS} \cdot \mathrm{m}^{-1}=1 \mathrm{mmho} / \mathrm{cm}$.

${ }^{y_{9}}=$ no firing with fully green turf, $1=$ most complete firing with straw-brown.

${ }^{*},{ }^{* *},{ }^{* *}$ Significantly different from the control at $P \leq 0.05,0.01$, or 0.001 , respectively, within column by Tukey's honestly significant difference test.
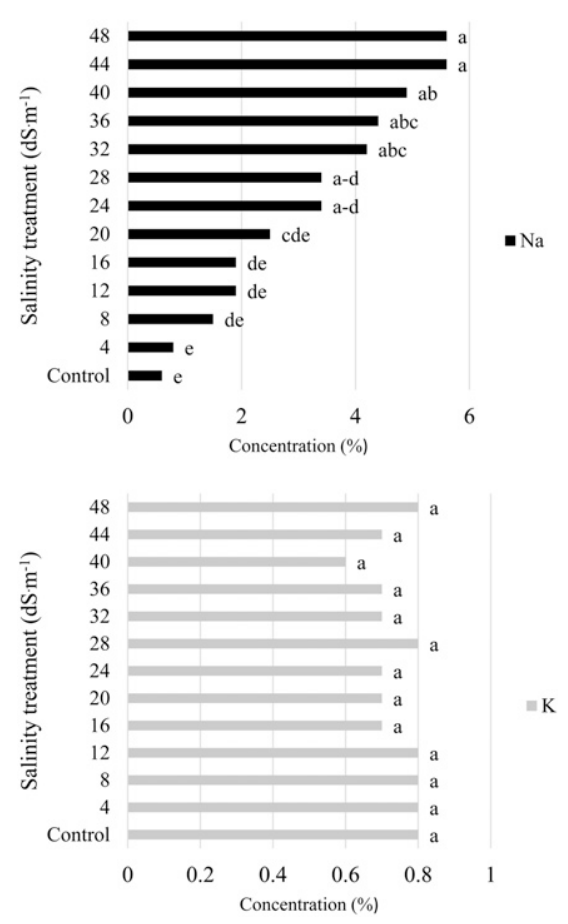

Fig. 1. Shoot sodium $(\mathrm{Na}+)$ and potassium $(\mathrm{K}+)$ ion concentrations of 'Riviera' common bermudagrass as influenced by 12 salinity treatments ranging from 4 to $48 \mathrm{dS} \cdot \mathrm{m}^{-1}$ and control at the end of $30 \mathrm{~d}$ of treatment. Bars labeled with the same lowercase letter are not significantly different using Tukey's honestly significant difference test $(P \leq 0.05) ; 1$ $\mathrm{dS} \cdot \mathrm{m}^{-1}=1 \mathrm{mmho} / \mathrm{cm}$.

treatment maintained a mean NDVI value of $\geq 0.773$ throughout the $\mathrm{ex}^{-}$ periment. The turf color index value and NDVI measured with a turf color meter (Field Scout TCM 500 NDVI) by Zulkaliph et al. (2013) and Xiang et al. (2018), respectively, also observed a decrease in value with an increase in the level of salinity. The decrease in LF value at 0 DAT for treatments $28-48 \mathrm{dS} \cdot \mathrm{m}^{-1}$ was not detected by NDVI measuring device. Also, the NDVI values of salinity treatments 4 and $8 \mathrm{dS} \cdot \mathrm{m}^{-1}$ were not significantly different from the control on all rating days. This trend suggests that the device could not detect the slight increase in firing in our study, which could be due to the limited area the device measured. The turf color meter (Field Scout TCM 500 NDVI) NDVI used in this study measured the reflected light from an $\approx 3$-inch-diameter section of the total of 4 inches of the lysimeter. An advantage human evaluators possess over an NDVI measuring device is the ability to integrate over the turfgrass plant for measurement.

Pearson's correlation coefficient $(r)$ for the relationship between LF and NDVI was 0.93 at $P<0.001$, revealing a strong positive correlation between the two parameters. The high Pearson's correlation coefficient between LF and NDVI in this study corresponds well with the 0.95 value obtained by Xiang et al. (2017, 2018), suggesting that NDVI could serve as a supplementary tool to measure the magnitude of salinity stress in turfgrasses because it requires no prior training. However, visual ratings are not consistent among evaluators and require training and experience to attain satisfactory proficiency in evaluation. (Bell et al., 2002a; Horst et al., 1984). A turfgrass manager of facilities that use recycled water for irrigation can use NDVI with little training to quickly and efficiently identify areas that show salinity stress to implement sitespecific leaching and soil amendment application. The constraints of a limited sample area could be mitigated using low-altitude aerial platforms, which opens the door for managers to implement precision turfgrass management to address salinity stress at facilities. Also, such techniques could benefit turfgrass breeders in developing highthroughput field-based assessment of plant traits for identifying salinity resistant turfgrasses.

The multiple linear regression analysis results revealed that there is a significant relationship $(P<0.001)$ between salinity concentrations and treatment days with a model coefficient of determination $\left(r^{2}\right)$ of 0.86 and 0.76 for $\mathrm{LF}[\mathrm{LF}=10.35-$ 0.09 (treatment days) -0.09 (salinity concentration $)]$ and NDVI [NDVI = $0.89-0.005$ (treatment days) 0.004 (salinity concentration)], respectively. The high $r^{2}$ value suggests that the data showed a linear response to salinity stress with LF and NDVI decreasing linearly as the salinity concentration and treatment days increased. Bermudagrasses have exhibited a linear trend when subjected to limited and multiple salinity treatments in previous 
Table 4. Normalized difference vegetation index (NDVI) values of 'Riviera' common bermudagrass for 12 salinity treatments and control on 11 rating dates.

\begin{tabular}{|c|c|c|c|c|c|c|c|c|c|c|c|}
\hline \multirow{2}{*}{$\begin{array}{l}\text { Salinity } \\
\text { treatment } \\
\left(\mathrm{dS} \cdot \mathrm{m}^{-1}\right)^{\mathrm{z}}\end{array}$} & \multicolumn{11}{|c|}{ NDVI $^{y}$} \\
\hline & \multicolumn{11}{|c|}{ Days after treatment } \\
\hline Control & 0.807 & 0.809 & 0.796 & 0.790 & 0.794 & 0.793 & 0.795 & 0.784 & 0.780 & 0.779 & 0.773 \\
\hline 4 & 0.808 & 0.801 & 0.791 & 0.782 & 0.789 & 0.786 & 0.791 & 0.763 & 0.773 & 0.762 & 0.761 \\
\hline 8 & 0.807 & 0.799 & 0.788 & 0.783 & 0.782 & 0.778 & 0.779 & 0.758 & 0.747 & 0.739 & 0.740 \\
\hline 12 & 0.800 & 0.797 & 0.777 & 0.772 & 0.777 & 0.769 & 0.773 & 0.745 & 0.730 & $0.717 * * *$ & 0.725 \\
\hline 24 & 0.796 & 0.774 & 0.752 & $0.735^{* *}$ & 0.742 * & $0.727 * * *$ & 0.740 ** & $0.685^{* * *}$ & $0.681 * * *$ & $0.658 * * *$ & $0.671 * * *$ \\
\hline 28 & 0.788 & 0.764 & $0.745^{*}$ & $0.734^{* *}$ & $0.731 * * *$ & $0.704 * * *$ & $0.728 * * *$ & $0.681 * * *$ & $0.668 * * *$ & $0.653 * * *$ & $0.657 * * *$ \\
\hline 32 & 0.791 & 0.771 & $0.743^{*}$ & $0.726 * * *$ & $0.724 * * *$ & $0.703 * * *$ & $0.722 * * *$ & $0.660 * * *$ & $0.640 * * *$ & $0.613^{* * *}$ & $0.607 * * *$ \\
\hline 36 & 0.781 & $0.741 * * *$ & $0.716^{* * *}$ & $0.691 * * *$ & $0.689 * * *$ & $0.676 * * *$ & $0.699 * * *$ & $0.650 * * *$ & $0.645^{* * *}$ & $0.606^{* * *}$ & $0.603 * * *$ \\
\hline 40 & 0.772 & $0.722 * * *$ & $0.679 * * *$ & $0.657 * * *$ & $0.657 * * *$ & $0.645^{* * *}$ & $0.647 * * *$ & $0.555^{* * *}$ & $0.560 * * *$ & $0.519 * * *$ & $0.516 * * *$ \\
\hline 44 & 0.759 & $0.713^{* * *}$ & $0.655^{* * *}$ & $0.620 * * *$ & $0.618 * * *$ & $0.606 * * *$ & $0.614^{* * *}$ & $0.524 * * *$ & $0.513 * * *$ & $0.487 * * *$ & $0.468 * * *$ \\
\hline
\end{tabular}

${ }^{\mathrm{z}}$ Riviera' common bermudagrass was evaluated by consecutively irrigating with 12 salinity concentrations $\left(\right.$ ranging from 4 to $\left.48 \mathrm{dS} \cdot \mathrm{m}^{-1}\right)$ in increments of $4 \mathrm{dS} \cdot \mathrm{m}^{-1}$ and via manual overhead irrigation for $30 \mathrm{~d} ; \mathrm{ldS} \cdot \mathrm{m}^{-1}=1 \mathrm{mmho} / \mathrm{cm}$

${ }^{y}$ NDVI was measured using turf color meter (FieldScout TCM 500 NDVI; Spectrum Technologies, Aurora, IL).

${ }^{*},{ }^{* *},{ }^{* *}$ Significantly different from the control at $P \leq 0.05,0.01$, or 0.001 , respectively, within column by Tukey's honestly significant difference test.

studies (Alshammary et al., 2008; Dudeck et al., 1983; Uddin et al., 2011, 2012). Bermudagrass showed a linear decrease in shoot growth rate, shoot weight, shoot $\mathrm{Na}^{+}$, and $\mathrm{Cl}^{-}$concentration and shoot visual ratings compared with five other $\mathrm{C} 4$ grasses (Marcum and Murdoch, 1994). A linear decrease in the percentage of green leaf area was reported in 'Midiron' hybrid bermudagrass [C. dactylon $\times$ C. transvaalensis (Marcum et al., 2005)].

This study provided a visual and spectral reflectance response of 'Riviera' common bermudagrass subjected to 12 salinity treatments for a period of $30 \mathrm{~d}$. The results showed that LF and NDVI exhibited a decreasing linear trend with increasing concentrations of salinity and days of treatment. However, irrigating with a high salinity concentration of 48 $\mathrm{dS} \cdot \mathrm{m}^{-1}$ for $30 \mathrm{~d}$ did not completely fire (a rating of 1 ) 'Riviera'. Also, 'Riviera' maintained an LF value above 6 when irrigated at $20 \mathrm{dS} \cdot \mathrm{m}^{-1}$ for $30 \mathrm{~d}$. The plant tissue analysis results indicate that the accumulation of $\mathrm{Na}^{+}$ions could be one of the major causes of LF observed in our study. The assessment techniques, LF and NDVI, could be used together to estimate the magnitude of salinity stress due to the high positive correlation. Therefore, untrained personnel could use NDVI to assess salinity stress faster and efficiently. However, handheld NDVI measuring devices need to be used with caution because the limited area measured by these devices could lower the ability to detect the increase in salinity stress. On a larger scale, NDVI can be evaluated using mobile sensor devices or unmanned aerial vehicles, which opens the door for that manager to implement precision turfgrass management to address salinity stress at facilities known to be high risk.

\section{Literature cited}

Alshammary, S.F., G. Hussain, and Y.L. Qian. 2008. Response of four warm-season grasses to saline irrigation water under arid climate. Asian J. Plant Sci. 7:619-627, doi: 10.3923/ajps.2008.619.627.

Bell, G.E., D.L. Martin, S.G. Wiese, D.D. Dobson, M.W. Smith, M.L. Stone, and J.B. Solie. 2002a. Vehicle-mounted optical sensing: An objective means for evaluating turfgrass quality. Crop Sci. 42:197-201, doi: 10.2135/cropsci2002.1970.

Breuninger, J.M., M.S. Welterlen, B.J. Augustin, V. Cline, and K. Morris. 2013. The turfgrass industry, p. 37-104. In: J.C. Stier, B.P. Horgan, and S.A. Bonos (eds.). Turfgrass: Biology, use, and management. Amer. Soc. Agron., Crop Sci. Soc. Amer., Soil Sci. Soc. Amer., Madison, WI. doi: 10.2134/agronmonogr56.c2.

Devitt, D., R. Morris, R.D. Kopec, and M. Henry. 2004. Golf course superintendents' attitudes and perceptions toward using reuse water for irrigation in the southwestern United States. HortTechnology 14:577-583, doi: 10.21273/HORTTECH. 14.4.0577.
Dudeck, A.E., S. Singh, C.E. Giordano, T.A. Nell, and D.B. McConnell. 1983. Effects of sodium chloride on Cynodon turfgrasses. Agron. J. 75:927-930, doi: 10.2134/agronj 1983.00021962007500060017x.

Guimaraes, F.V.A., C.F. Lacerda, E.C. Marques, C.E.B. Abreu, B.F. Aquino, J.T. Prisco, and E. Gomes-Filho. 2012. Supplemental $\mathrm{Ca}^{2+}$ does not improve growth but it affects nutrient uptake in $\mathrm{NaCl}$-stressed cowpea plants. Braz. J. Plant Physiol. 24:9-18, doi: 10.1590/ S1677-04202012000100003.

Harivandi, M.A. 2004. A review of sports turf irrigation with municipal recycled water. Acta Hort. 661:131-136, doi: 10.17660/ActaHortic.2004.661.16.

Horst, G.L., M.C. Engelke, and W. Meyers. 1984. Assessment of visual evaluation techniques. Agron. J. 76:619-622, doi: 10.2134/ agronj1984.00021962007600040027x.

Koch, M.J. and S.A. Bonos. 2010. An overhead irrigation screening technique for salinity tolerance in cool-season turfgrasses. Crop Sci. 50:2613-2619, doi: 10.2135/ cropsci2010.03.0134.

Liphschitz, N. and Y. Waisel. 1974. Existence of salt glands in various genera of the Gramineae. New Phytol. 73:507513, doi: 10.1111/j.1469-8137.1974. tb02129.x.

Marcum, K.B. and C.L. Murdoch. 1990. Growth responses, ion relations, and osmotic adaptations of eleven $\mathrm{C} 4$ turfgrasses to salinity. Agron. J. 82:892-896, doi: 10.2134/ agronj1990.00021962008200050009x.

Marcum, K.B. and C.L. Murdoch. 1994. Salinity tolerance mechanisms of six C4 turf- 
grasses. J. Amer. Soc. Hort. Sci. 119:779784, doi: 10.21273/JASHS.119.4.779.

Marcum, K.B. 1999. Salinity tolerance mechanisms of grasses in the subfamily Chloridoideae. Crop Sci. 39:1153-1160, doi: 10.2135/cropsci 1999.0011183X003900040034x

Marcum, K.B., M. Pessarakli, and M.K. David. 2005. Relative salinity tolerance of 21 turf-type desert saltgrasses compared to bermudagrass. HortScience 40:827-829, doi: 10.21273/HORTSCI.40.3.827.

Marcum, K.B. and M. Pessarakli. 2006. Salinity tolerance and salt gland excretion efficiency of bermudagrass turf cultivars. Crop Sci. 46:2571-2574, doi: 10.2135/ cropsci2006.01.0027.

Morris, K.N. and R.C. Shearman. 2008. NTEP turfgrass evaluation guidelines. 15 Dec. 2019. <http://www.ntep.org/ reports/ratings.htm $>$.

Munns, R. 1993. Physiological processes limiting plant growth in saline soil: Some dogmas and hypotheses. Plant Cell Environ. 16:15-24, doi: 10.1111/j.13653040.1993.tb00840.x.

Parida, A.K. and A.B. Das. 2005. Salt tolerance and salinity effects on plants: A review.
Ecotoxicol. Environ. Saf. 60:324-349, doi: 10.1016/j.ecoenv.2004.06.010.

Sonmez, N.K., Y. Emekli, M. Sari, and R. Bastug. 2008. Relationships between spectral reflectance and water stress conditions of bermudagrass (Cynodon dactylon L.). N. Z. J. Agr. Res. 51:223-263, doi: 10.1080/00288230809510451.

Throssell, C.S., G.T. Lyman, M.E. Johnson, G.A. Stacey, and C.D. Brown. 2009a. Golf course environmental profile measures water use, source, cost, quality, and management and conservation strategies. Appl. Turfgrass Sci. 6:1-20, doi: 10.1094/ATS-2009-0129-01-RS.

Trenholm, L.E., R.N. Carrow, and R.R. Duncan. 1999. Relationship of multispectral radiometry data to qualitative data in turfgrass research. Crop Sci. 39:763-769, doi: 10.2135/cropscil999.0011183X003900030025x.

Uddin, M.K., A.S. Juraimi, M.R. Ismail, R. Othman, and A.A. Rahim. 2011. Relative salinity tolerance of warm season turfgrass species. J. Environ. Biol. 32:309-312.
Uddin, M.K., A.S. Juraimi, M.A. Hossain, M.R. Ismail, O. Radziah, and A.A. Rahim.

2012. Physiological and growth response of tropical turfgrass to salinity stress. ScientificWorldJournal 2012:1-10, doi: 10.1100/ 2012/905468.

Xiang, M., J.Q. Moss, D.L. Martin, K. Su, and B.L. Dunn. 2017. Evaluating the salinity tolerance of clonal-type bermudagrass cultivars and an experimental selection. HortScience 51:185-191, doi: 10.21273/HORTSCI10773-16.

Xiang, M., J.Q. Moss, D.L. Martin, K. Su, and B.L. Dunn. 2018. The salinity tolerance of seeded-type common bermudagrass cultivars and experimental selections. HortTechnology 28:276-283, doi: 10.21273/ HORTTECH03975-18.

Zulkaliph, N.A., A.S. Juraimi, K. Uddin, M.R. Ismail, M.S. Ahmad-Hamdani, and U.A. Nahar. 2013. Screening of potential salt tolerant turfgrass species in peninsular Malaysia. Aust. J. Crop Sci. 7:1571-1581. 